\title{
The Origin of the Universe: Big Bang to God Theory
}

\author{
Dastagiri M.B. (PhD, Hon. DL, Hon. DSc) \\ Principal Scientist, ICAR-National Academy of Agricultural Research \\ Management, Rajendranagar, Hyderabad, India
}

Doi: 10.19044/esj.2018.v14n33p143 URL:http://dx.doi.org/10.19044/esj.2018.v14n33p143

\begin{abstract}
The universe is full of mystical things. Since ages, the belief that God became the Universe is a theological doctrine that has been developed. Evolutionary biologists and Modern scientists still believes in Big Bang theory. Many thinkers, theologians, philosophers, and scientists are unable to confirm the exact process of the origin of the universe. Hence, this paper focuses on analyzing the history of theologians, mythologists, philosophers, cosmologists and scientists research evidences, insights, theories, and rationales to find out about the origin of the universe. The study uses metaanalysis of universe origin scriptures, research, insights, and bibliographies which was put forth by theologians, philosophers, cosmologists, and scientists. The study found that as per Bhagavad-Gita, God is the source of all spiritual, intellectual, and material world. In 1996, Pastor Bob Burridge of the Genevan Institute for Reformed Studies reveals that as per Christian theology, God becoming the universe is not accordant with it. In the 1940s, Charles Hartshorne identified pandeism as a possible model of God's nature as God is capable of changing. In 2001, Scott Adams surmised that an omnipotent God annihilated himself in the Big Bang. This is considered as per mythologist's world created from dead deity physical substances. All Catholic scientists reported that God's light and love revealed his creation. Physicist Bernard Haisch in his book entitled "The God Theory" concluded that the deity became the universe. Alan Dawe's (2011) book titled "The God Franchise" concludes that human knowledge is a briefly separated piece of God's skill. Raphael Lataster (2013), Australian religious studies Scholar, projected that "Pandeism is the future God-concept of all". There is a long list of Catholic scientists who in their quest for learning maintained God at the origin of all existence. Theology and mythology proofs are not conforming with both science and philosophy. The Evolving God concept is also a wrong idea of metaphysics. If it is so, man would have been found under developed state. Jafree Ozwald explains that based on human request, the universe is not able to fulfill it but God does. The universe is not God. God is God. The
\end{abstract}


study concludes that God created the universe from nothing and $\mathrm{He}$ is yet to manifest Himself. God is a supernatural power and has a divine holy nature that is omnipresence, omnipotence, and omniscience. The study suggests that the sharing of knowledge, debate, discussions, and consensus based on their evidences and perceptions among theologists, philosophers, mythologists, and scientists on the universe origin is a future task.

Keywords: Universe, Origin, Big Bang, Theology, Philosophy, Science, God

\section{Introduction}

The universe is full of mystical things. Historically, the theological doctrines prophecy is that God became or manifest through the universe. Contrastingly, Evolutionary biologists and Modern scientists still believe in Big Bang theory. Georges Lemaitre, 20th century physicist, was the pioneer who put forward the "big bang" theory. Higgs Englert (2013) received Physics Nobel for God particle research. If there is one thing Believer and Atheist can agree upon is on the beauty, the power, and majesty of creation. The Judeo-Christian belief states that creation manifests the light and love of God to humans. In general, science searches how? And Faith searches why? This is in regards to the type of answers to questions.

The legacy of Carl Sagan, Richard Dawkins, and Stephen Hawking is continuing and all of them were right from their own point of view. Sagan, a famous astronomer and cosmologist, said that belief in God and an afterlife amounts to "wishful thinking." Dawkins, an evolutionary biologist, claims with near certainty that there is no God and faith is "a fixed false belief." Stephen Hawking, a theoretical physicist and cosmologist, calls heaven a myth created for "people afraid of the dark" (Carl Sagan, 2014).

Isaac Newton belief was on the fact that the universe is governed by a mystical god. Albert Einstein, a supreme genius known to the world and by his work, gave us an understanding of the way the universe works. Stephen Hawking, famous astrophysicist, foresees that humanity should explore space colonization particularly on Mars. Of late, NASA also realized this and they will be exploring Mars colonization by 2030 (Dastagiri, 2017). At present, based on the concept of one planet species, we simply have a choice to make because of species extinction. Otherwise, we will explore the colonization of other world and live more millions or billions of years.

Mankind and planets are both created. Man has achieved cosmic new heights because of scientific revolutions. Dastagiri (1997) reported that natural resources are beneficial to humanity. Man's new vision and mission must be Mars colonization and Moon industrialization. However, this is a possible scientific space and cosmic revolutions (Dastagiri, 2017). Dastagiri 
(2013) formulated the New Economics of Moon industrialization and Mars colonization.

It is evident that the chances of man survival will be more when he finds regularities in the outer world. To quote some theories and principles, Darwin's General Theory (fittest will survive) and Lemark principle (use and disuse principle) are exemplary examples. Since ages, these were adopted by man biologically and empirically (Rugina, 2003).

Science has confirmed that the universe have been developed over billions of years ago. The Bible says God created everything in six days. In the beginning, God created the heavens and the earth out of nothing in an instant. This is starting point of the universe, which is what scientists described as the "Big Bang."

\section{A Theology or Philosophy of Puzzle}

In God theory, the theological doctrines prophecy is that God became or manifest Himself through the universe. Believer and Atheist can agree that creation is awesome to behold. What the believer understands and the atheist denies is that God actually manifests Himself through the universe. However, one must always seek the truth with humility to ascertain it. I quote the words of Werner Heisenberg, who won the Nobel Prize for creating quantum mechanics: "superficial grasping of natural sciences makes atheist and utmost deep understanding is God."

Oxford Dictionary defined "Philosophy" as "love of wisdom or knowhow of fundamental truth (www.math)." It is difficult to find out scientifically ultimate reality exclusively with one reason. Philosophically, did we create laws of nature instead of discovering them? This point of view will have a huge impact on the human view point. This will help in rethinking in more advanced ways rather than preconceived ways. This will birth greater vision to theologians, philosophers, cosmologists, and scientist's evidences and experiences of the universe.

The present paper analyzes historical scriptures, evidences, insights, knowledge, ideas, and rationales that bridge the universe origin in regards to Theology, Philosophy, Mythology, Cosmology in particular, and Science in general. The specific objectives of the paper are:

1. To analyze and trace the universe origin from the evidences of Theology, Mythology, Philosophy, Cosmology, and Science.

2. To scrutinize the mysteries and possibilities of universe creation and the wellbeing of humanity.

3. To advocate the prophecy of the universe origin to human beings. 


\section{Data and Methodology}

The study was carried out based on the framework of vision and metaanalysis of universe origin research which has been done by theologians, philosophers, mythologists, cosmologists, and scientists. In God theory, theological doctrine states that God manifested Himself through the universe. The study analyzes historical theologians, philosophers, cosmologists and scientist's religious scriptures, bibliographical research evidences, insights, theories, and rationales. Also, it finds out the origin of the universe. It also analyzes the theory and philosophy that bridges theologians, mythologists, philosophers, cosmologists, and scientists. Finally, the study suggests and advocates the prophecy of universe origin to human beings.

\section{Results}

The study thoroughly analyzed the historical theologians, philosophers, cosmologists and scientist's religious scriptures, bibliographical research evidences, insights, and rationales. However, the results of the universe origin are grouped under theology, mythology, philosophy, cosmology, and science.

\section{Theology (Study Nature of Divine)}

The major world religions are Hinduism, New Age spirituality, Buddhism, Islam, and Christianity. Based on belief systems and their perspectives of God, analysts found vast diversity. Hindus confess multitudes of gods and goddesses. Buddhists stated that there is no deity. New Age Spirituality followers believe they are God. Muslims believe in a powerful but unknowable God. Christians believe a loving God who created us to know him (Marilyn Adimson).

Since ages past, the belief that God became the universe is the doctrine of theologies and religious scriptures. Based on this philosophy or theory, God ended His existence or act as a supernatural conscious power. Thus, researchers used the term "pandeism," which combines various aspects of pantheism and deism (Seen, 2009; Paul Bradely, 2011; Alan, 2011). A similar concept is pantheism whereby the creator became a part of the universe and remains in other part as transcendent.

It is our faith that teaches us that God created the universe from nothing, and He did so out of the love He has for us. No one has ever proven otherwise. In essence, there are two things every person needs: light and love. I know of no atheist who does not appreciate the cosmos, galaxies of sun, moon, and stars which are essential for human life otherwise human life is in danger.

Pope Benedict says, "God gifts primarily to humans are the heavens; cosmos, planets, galaxies of stars. Later, He provides for his creature life and 
lively requirement of food, water, light, and time. He has designed laws." Pontiff says "Light and love" is the primitive of "the primordial original power that moves the universe" (Zenit, 2005). As the Magi discovered following the Star, God's creation is the first step towards the light and love of God made manifest in Jesus Christ. The Magi were the scientists of their time. In their pursuit of truth, they studied not only the material universe but the Hebrew Scriptures as well.

As per Bhagavad-Gita, what God created is the source of all spiritual, intellectual, and material world. He is the beginning and the end. The cosmic universe is under his divine control. He is superior to all his creatures (ISKON, 2016).

\section{God's Purpose of Universe Creation}

With that in mind, God perspectives and human perspectives are different. Human act based on his desire and requirements, whereas God acts as an intelligent designer. God designed the universe and decorated it to be full of cosmos, living and non-living creatures, and beauty to attract us with astonishing diversity and glory of endless events with reliable reality for the human mind and senses. His creativity is magnificent and full of perfection. With the Geometry of sacred cosmos, the humans, plants, animals, and other living creature's geometry are coordinating and cooperating with nature, and His will and mightiness beyond human perception. God is compassionate, merciful and gracious, and His wishes are secrets. God created the universe to show his mightiness and the omnipotence of His creativity.

\section{Revelation of God and the Universe}

Jafree Ozwald explains in detail how to ask the universe for what you want: When human requests from the universe continuously with forceful affirming voice requesting any good wishes. When he doubts the universe revelation because the universe is blind, deaf and dumb, then the heaven reveals the glory of God and His design. The universe is not God. God is God. "Asking the universe" is merely a blunt or false god which is called idolatry. Bottom line: don't get high on anything but God (David Allen, 2001).

\section{Mythology (Story Telling of People)}

Edward Burnett (1871) reported that many ancient mythologies reported that from physical substance of a dead deity, the world was created. In Babylonian mythology, the young god, Marduk slew Tiamat, made the world from her body. Similarly, Norse mythology posited that Odin and his brothers, Vili and Vé, defeated a frost giant, Ymir, and made the world from his skull. Chinese mythology of the Three Kingdoms era, physical world such as rivers, mountains, the sun and 
Moon etc, created elements from the body of Pangu creator. Such stories did not go so far as to identify the designer of the world as being one as having used his or her own body to provide the material. However, one of such example exists in Polynesian myth. In the islands of the Pacific, the idea of Supreme Deity manifests in a divinity that New Zealanders call Tangaroa, the Hawaiians Kanaroa, the Tongans and Samoans Tangaloa, and The Georgians islanders call Taaroa.

\section{Philosophy (Rational Enquiry of Existence) Ancient Philosophy}

Francis Edward Peters (1967), who had pantheism genius, traced the philosophy of the Milesians. In his Greek Philosophical Terms, the center of the Pythagorean tradition shows that Psyche have little or no influence on pan-vitalism or pan-deism which is the major legacy of Milesians. Based on Milesian philosopher, Anaximander advocated rational principle to draw everything in the world made from single material which briefly originated from the primitive world.

Friedrich Nietzsche (1873), a Greek philosopher, commented on Anaximander view as an illegal liberation from an everlasting being. Anaximander was among the material monists. This was along with Thales that has faith that all was possessed of water, Anaximenes, who believed it was air, and Heraclitus, who believed it to be fire. Gottfried Große in his 1787 interpretation of Pliny, the Elder's History of Nature, defines Pliny as a first pan deist statue.

In the 9th century, Johannes Scotus Eriugena proposed in his great work, De divisione naturae, that God is the origin of everything and end of all. Whatever he created will finally return to him. He stated that creation is a divine effort to know himself (Jeremiah Genest, 1998). Eriugena's hypothesis states that God enters an ambit of time and space. In that realm, ideas will develop, array, defect, and vanish. He was supported by the notions of Plato and Aristote. Eriugena's work was condemned by a council at Sens by Honorius III (1225), who states this as "crawling with caterpillars of heretical perversity," and by Pope Gregory XIII in 1585. Since ages, this type of theories has been suppressed.

\section{Medieval Philosophy}

The ideas of Spinoza lay corner stone establishment of pandeism. Giordano Bruno conceived that God is eternal and permanent. Hence, he is not interested in human affairs. However, in the $17^{\text {th }}$ Century, Baruch Spinoza is a pioneer in the conception of deistic reason for the perception of Pantheistic God. 
British philosopher, Thomas Paine, based on his philosophical thesis rational enquiry makes use of the deistic approach. John and Robert (2007) reported that as per Encyclopedia of American Philosophy, "Later Unitarian Christians (such as William E. C), transcendentalists (Ralph Waldo Emerson and Henry D. T), writers (Walt Whitman) and some pragmatists (William J) seized more pantheist or pandeist stand and rejected God as separate from the world.

First, a Dutch naturalist, Franz W. Junghuhn, described a religious philosophy that incorporates deism and pantheism. His book was banned at a time in Austria and parts of Germany as an attack against Christianity. In 1884, Sabine Baring-Gould (1884), a theologian, contended that Christianity itself requires conflicting elements of pantheism and deism.

Italian phrenologist Luigi (1838) in his paper "Ferrarese in Memorie Riguardanti la Dottrina Frenologica" contradicted the Victor Cousin philosophy as a doctrine which perceives reason beyond humans which is against God. Also, he professed man as a chip of God announcing a kind of spiritual Pandeism. Cousin was branded as pantheist but differs from Spinoza and the Eleatics which states that God is a pure substance and is not a cause" (James Strong, 1894).

\section{Modern Philosophy}

In the 1940s, Charles Hartshorne identified pandeism as a possible model of God's nature as God is capable of changing. Hartshorne preferred pandeism to pantheism, explaining that "it is not really the theos that is described" (Charless Hartshome, 1964). Initially, he rejected pandeism because God is perfect to all others (Donald Luthor Jackson, 2012).

In 2001, Scott Adams published "God's Debris: A Thought Experiment," in which a fictional character puts forth a radical form of kenosis, surmising that an omnipotent God annihilated himself in the Big Bang (Scott Adams, 2001). He also stated that God's smaller unit's energy became the universe called "God Dust" and, furthermore, he was restored by a human. As per Simon Raven novel (1976), The Survivors includes manifestation of God. Therefore, the universe is God.

\section{Cosmology (Study of the Origin and Evolution of the Universe) a. Science}

Many Intellectuals simply believe that all reality must be weighed, measured, and quantified for it to exist. There is a long list of Catholic scientists who in their quest for learning maintained God at the origin of all existence. Roger Bacon, $13^{\text {th }}$ century mathematician, was considered to be the pioneer of the scientific method. Copernicus, $16^{\text {th }}$ century mathematician, 
was known for his heliocentric theory and he formulated the model of the universe. Nicolas Steno, of the $17^{\text {th }}$ century, was the pioneer of modern anatomy and geology. Gregor Mendel, of the $19^{\text {th }}$ century, is the father of genetics. Georges Lemaitre, $20^{\text {th }}$ century physicist, was the pioneer of "big bang" theory (Witness Lee).

b) Astronomy: Isaac Newton belief was that the universe was governed by a mystical god (that governed the universe). Albert Einstein supreme geniuses known to the world and his work gave us an understanding of the way the universe works. Stephen Hawking, famous astrophysicist, foresee that humanity should explore space colonization, particularly Mars, otherwise they would go into extinction. Of late, NASA also realized this and would be exploring Mars colonization by 2030 (Dastagiri, 2017). Higgs Englert (2013) obtained Physics Nobel for God particle research "for finding mechanism of subatomic particles origin which is useful to understand fundamental particle of God, by the ATLAS and CMS experiments at CERN's."

\section{Universe Origin: Accordant of Science and Philosophy Testimonials}

In response to Deepak Chopra, the famous astronomer, Stephen Hawking stated that our universe requires no creator. He stated that possible $10^{5}$ universes exist indicating an omniscient present. He concludes that God did not create but became the universe. Chopra commented that Hawking's finding represent only God's nature and not His existence.

Physicist Bernard Haisch has published two books: one in 2006 entitled "The God Theory" and the book entitled "The Purpose-Driven Universe" in 2010. He concluded that the deity became the universe and he rejected the viewpoints of atheists and traditional theists. Haisch shows evidences of fine tuning and mystical experiences arguments. Alan Dawe's (2011) book entitled "The God Franchise" concludes that human knowledge is a briefly separated piece of God skill. Raphael Lataster (2013), Australian religious studies Scholar, projected that "Pandeism is the future God-concept of all".

\section{Comparison to Eastern Philosophy}

Warren Sharpe (2002) wrote: To the Hindu, for example, God didn't create the universe, but God became the universe. However, the universe does not know. Similarly, Helena Petrovna Blavatsky, written in Mandukya Upanishad, stated that it is the same when a spider comes out from its web. Similar to Brahma, "Germ of unknown Darkness" is the material from which all evolves and develops, "as the web from the spider, as plant 
from soil, as foam from the water," etc. Brahma "expands", and became the Universe woven out of his own substance.

\section{Critiques and Evaluations}

Some theologians have criticized the notion of a Creator wholly becoming the universe. William Walker Atkinson (1911) reported that God's changing is contradictory to God's infinity and perfection and these are wrong models of the schools of Pandeism. He also said that God is changing means God is not permanent, infinite and eternal, and is identified as Nature. The Evolving God concept is also a wrong idea of metaphysics. If it is so, man would have been found when it was under developed state. This is Anthromorphic deity and a pantheistic Nature of God. Ahmad Ibn et al. (1993) reported that it is not confirming as per Islamic "Sharia law".

In 1996, Pastor Bob Burridge of the Genevan Institute for Reformed Studies wrote in his Survey Studies in Reformed Theology that God becoming the universe is not accordant with Christian Theology. He said that creator is different from creation and creatures will behave based on free will, morals, and ethics.

Consequently, we have lost our Foundation of REALITY, and we form the ever-changing "parts" of physical things governed by physical laws. Indeed, the idea of some of the old philosophies is true which states that "there is No Being; merely a Becoming." This conception is that of a Supreme Being who is growing, developing, and increasing in efficiency, wisdom, power, and character which is anything but God (William Walker Atkinson, 1911; David Allen, 2001).

\section{Conclusions}

The universe is full of mystical things. Historically, the theological doctrines prophecy is that God became or manifest the universe. Science has confirmed that the universe have been developed over billions of years. Science says in the beginning that the universe originated because of "Big Bang". However, the Bible says that the universe was instantly created by God. Many thinkers, theologians, philosophers, and modern scientists are unable to confirm the exact process of the origin of the universe. Hence, the study was navigated to analyze and trace the universe origin based on vision and meta-analysis of universe origin research.

\section{Religious Scriptures and Theological Doctrines Findings}

It is our faith which teaches that God created everything out of nothing. No one has ever proven otherwise. If there is one thing that Believer and Atheist believer can agree upon is the beauty, the power, and the majesty of creation. Hindus confess multitudes of gods and goddesses. Buddhists says 
that there is no deity. New Age Spirituality followers believe they are God. Muslims believe in a powerful but unknowable God. Christians believe in a loving God who created us to know him.

As per Bhagavad-Gita, God created the universe and is the source of all spiritual, intellectual, and material world. The cosmic universe is under his divine control. He is superior to all his creatures. In 1996, Pastor Bob Burridge of the Genevan Institute for Reformed Studies reveals that as per Christian theology, God becoming the universe is not accordant with it.

\section{Philosophical and Mythological Findings}

In the 1940s, Charles Hartshorne identified pandeism to be a possible model of God nature as God is capable of changing. In 2001, Scott Adams surmised that an omnipotent God annihilated Himself in the Big Bang. This was as per the mythologist's world created from dead deity physical substances. All Catholic scientists reported that the God's light and love revealed his creation. Chopra commented that Hawking's finding represent only God's nature and not His existence.

Physicist Bernard Haisch in the book entitled "The God Theory" concluded that the deity became the universe and rejected the viewpoints of atheists and traditional theists. Alan Dawe's (2011) concludes that human knowledge is a briefly separated piece of God's skill. Raphael Lataster (2013), Australian religious studies Scholar, projected that "Pandeism is the future God-concept of all". Milesian philosopher, Anaximander, advocated rational principle to draw everything in the world made from single material which briefly originated from primitive world origin.

\section{Cosmology and Science Findings}

There is a long list of Catholic scientists who in their quest for learning maintained God as the origin of all existence. The Evolving God concept is also a wrong idea of metaphysics. If it is so, man would have been found when it was under developed state.

Jafree Ozwald explains for human request what the universe is not able to fulfill but God does. The universe is not God. God is God. With that in mind, God perspectives and human perspectives are different. Human act based on his desire and requirements, whereas God acts as an intelligent designer. The study concludes that from nothing God created the universe and did not manifest as the universe. God is a supernatural power with a holy divine nature that is omnipresent, omnipotent, and omniscient.

\section{Way Forward}

"Superficial grasping of natural sciences makes atheist and utmost deep understanding is God." Philosophically, did we create laws of nature 
instead of discovering them? This point of view will have a huge impact on the human view point. This will help in rethinking in more advanced ways rather than preconceived. The study suggests that there must be debate, discussions, and consensus on their evidences and perceptions among theologists, philosophers, mythologists, evolutionary biologists, cosmologists, and natural scientists on universe origin.

\section{Acknowledgement}

I wish to thank Ms. Anjani Sneha for her help in the preparation of this research paper.

\section{References:}

1. Adams. S, (1957). God's Debris, p. 43-44.

2. Ahmmad ibn et al. (1993). Ibn Taymiyya against the Greek logicians, 1993, xxvi.

3. Alan Dawe, H. (2011). The God Franchise: A Theory of Everything.

4. Bob Burridge (1996). "Theology Proper: Lesson 4 - The Decrees of God", Survey Studies in Reformed Theology, Genevan Institute for Reformed Studies.

5. Carl Sagan (2014). Took My Faith - and Gave Me Awe - OnFaith, https://www.onfaith.co/onfaith/2014/03/10/carl-sagan-took-myfaith-and.../31220

6. Dastagiri, M.B., Kantharaju, M.L., \& Nadagoud, V.B. (1997). " G-7 Countries Natural Resources Utilization in the Global Scenario: Policies and Prospects" Indian Journal of Economics, issue3. PP. 199. 214.

7. Dastagiri, M.B. (2013). "New Economics: Nature's Laws". 2: 672. doi:10.4172/scientificreports.672

8. Dastagiri, M.B. (2017). "The Theory and Economics of MARS and MOON Colonization: Steps and Policy Advocacy". European Scientific Journal. France, 13(28):239-253.

9. David Allen (2014). "Don't Ask the Universe, Ask God!" on June 12, 2014 in Bible, Theology 2 http://drdavidlallen.com/bible/dont-askthe-universe-ask-god/

10. David Allen (2014). on June 12, in Bible, Theology 2.

11. Donald Luther Jackson (2012). Religious Lies. "Religious Truths: It's Time to Tell the Truth"!, page 175.

12. Edward Burnett Tylor (1871). Primitive culture: researches into the development of mythology, philosophy, religion, art, and custom, 312-313. 
13. Fethullah Gülen (2001). Why did God Create the Universe?, https://fgulen.com/en/fethullah-gulens-works/faith/questions-andanswers/244 on 13 September.

14. Ferrarese Luigi (1838). Memorie risguardanti la dottrina frenologica. p. 15.

15. Francis Peters, E. (1967). Greek Philosophical Terms: A Historical Lexicon, p. 169 (NYU Press).

16. Friedrich Nietzsche (1873). Philosophy in the Tragic Age of the Greeks $\S 4$.

17. Große Gottfried (1787). Naturgeschichte: mit erläuternden Anmerkungen. p. 165.

18. Genevan Institute for Reformed Studies. http://www.genevaninstitute.org/about/

19. Higgs Englert (2013). The Nobel Prize in Physics 2013 NobelProze.org. https://www.nobelprize.org/prizes/physics/2013/summary/

20. ISKON (2016). "Origin of the universe: Srimad Bhagavatam and the Big Bang Theory” By Brajahari das Posted by ISKCON desire tree network on June 25.

21. Jeremiah Genest \& John Scottus Eriugena (1998). Life and Works.

22. John Lachs \& Robert Talisse (2007). American Philosophy: An Encyclopedia, p. 310.

23. Marilyn Adimson. "The major world religions and their beliefs about God. Hinduism, Buddhism, Islam, Christianity, and New Age Spirituality" https://www.printfriendly.com/p/g/EJB9rV.

24. Rugina, AN. (2003). Nobel Laureate: Paul A. Samuelson (1915- ). International Journal of Social Economics 30: $424-452$.

25. Raphael Lataster (2013). There was no Jesus, there is no God: A Scholarly Examination of the Scientific, Historical, and Philosophical Evidence \& Arguments for Monotheism. p. 165. ISBN 1492234419.

26. Scott Adams (2001). God's Debris. p.43 ISBN 0-7407-2190-9.

27. Simon Raven (1976). The Survivors, P. 90.

28. The Subjective Experience of the Indwelling Christ, by Witness Lee THE MANIFESTATION OF THE DIVINE CHARACTERISTICS THROUGH ALL THE CREATED THINGS IN THE UNIVERSE https://www.ministrysamples.org/excerpts/THE-

MANIFESTATION-OF-THE-D.

29. Warren Sharpe, B. (2002). Philosophy for the Serious Heretic: The Limitations of Belief and the Derivation of Natural Moral Principles. p. 396 ISBN 0-595-21596-3.

30. William Turner. The Catholic Encyclopedia: John Scotus Eriugena. 
31. Witness Lee. https://www.ministrysamples.org/excerpts/THEMANIFESTATION-OF-THE-D.

www.math.lsa.umich.edu/news/CID_math_Bass.pdf.

32. Zenit (2005). Creation Reveals God and His Love, Says Benedict XVI - ZENIT ... https://zenit.org/articles/creation-reveals-god-and-hislove-says-benedict-xvi/ 